Journal of Pharmaceutical Science and Clinical Research, 2019, 01, 16-28

DOI: $10.20961 /$ jpscr.v4i1.27212

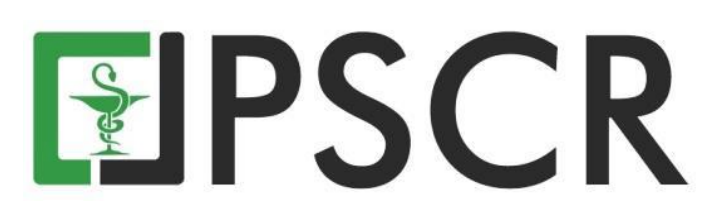

\title{
Uji Stabilitas dan Aktivitas Gel Handsanitizer Ekstrak Daun Kemangi
}

\author{
Sholichah Rohmani dan Muhammad A.A. Kuncoro \\ Prodi Farmasi, Fakultas Matematika dan Ilmu Pengetahuan Alam UNS, Surakarta \\ *email korespondensi : licha.apt@gmail.com
}

\begin{abstract}
Abstrak: Daun kemangi memiliki potensi kuat yang beraktivitas untuk menghambat pertumbuhan bakteri S.aureus. Untuk meningkatkan keefektifitasan dalam pemanfaatan potensi ekstrak daun kemangi, maka dibuat dalam bentuk sediaan yang praktis dan mudah digunakan. Salah satu bentuk sediaan yang efektif untuk terapi topikal adalah handsanitizer gel. Faktor yang mempengaruhi kualitas sediaan gel salah satunya adalah penggunaan bahan tambahan seperti gelling agent, dimana pemilihan jenis dan konsentrasi gelling agent akan menentukan kestabilan gel yang terbentuk, sehingga penelitian ini bertujuan untuk mengetahui pengaruh konsentrasi CMC Na sebagai gelling agent terhadap stabilitas fisik dari gel handsanitizer ekstrak daun kemangi sebagai antibakteri. Ekstrak daun kemangi diperoleh dengan metode maserasi menggunakan pelarut etanol 96\%. Ekstrak yang dihasilkan diformulasikan dalam sediaan gel dengan penambahan $\mathrm{CMC} \mathrm{Na} 1 \%(\mathrm{~F} 1), 2 \%(\mathrm{~F} 2), 3 \%(\mathrm{~F} 3)$. Setiap formula dilakukan pengujian stabilitas fisik meliputi uji organoleptis, uji homogenitas, uji daya sebar, uji daya lekat, uji pH, dan cycling test selama 6 siklus serta uji aktivitas antibakteri. Dari hasil penelitian diketahui bahwa perbedaan konsentrasi CMC Na sebagai gelling agent berpengaruh terhadap konsistensi, daya lekat, daya sebar, dan aktivitas antibakteri dari sediaan gel handsanitizer ekstrak daun kemangi, dimana peningkatan konsentrasi CMC Na maka konsistensi semakin meningkat, daya lekat semakin lama, daya sebar semakin kecil, dan aktifitas antibakterinya semakin menurun, namun perbedaan konsentrasi CMC Na tidak berpengaruh terhadap $\mathrm{pH}$ dan homogenitasnya. Gel handsanitizer ekstrak daun kemangi memiliki stabilitas yang baik sebelum maupun sesudah cycling test.
\end{abstract}

Kata kunci : Gel handsanitizer; CMC Na; Uji stabilitas; Aktivitas antibakteri

Abstract. Stabilization and Activity Test Handsanitizer Gel of Kemangi Leaves Extract. Stabilization and activity test handsanitizer gel of kemangi leaves extract. Basil leaves have strong potential for activity to inhibit the growth of S. aureus bacteria. To improve effectiveness in the utilization of the potential of basil leaf extract, it is made in a dosage form that is practical and easy to use. One form of effective preparation for topical therapy is gel handsanitizer. Factors affecting the quality of gel preparation are the use of excipients such as gelling agents, where the selection of types and gelling agent concentration will determine the stability of the gel formed, so this study aims to determine the effect of $\mathrm{Na} \mathrm{CMC}$ concentration as a gelling agent on the stability of gel handsanitizer in basil leaf extract. as antibacterial. Basil leaf extract was obtained by maceration method using $96 \%$ ethanol solvent. The resulting extract was formulated in a gel preparation with the addition of CMC Na $1 \%(\mathrm{~F} 1), 2 \%(\mathrm{~F} 2), 3 \%(\mathrm{~F} 3)$. Each formula was tested for physical properties (organoleptic, homogeneity, dispersion, stickiness, and $\mathrm{pH}$ ), and stability test (cycling test for 6 cycles) and antibacterial activity test. From the results of the study, it was found that the difference in $\mathrm{Na} \mathrm{CMC}$ concentration as a gelling agent had an effect on consistency, stickiness, dispersibility, and antibacterial activity of the handsanitizer gel preparations of basil leaf extract, where consistency was increasing, adhesion was longer, 
dispersing power was smaller, and activity the antibacterial decreased, but the difference in the concentration of $\mathrm{CMC}$ Na did not affect the $\mathrm{pH}$ and homogeneity. Gel handsanitizer of basil leaf extract has good stability both before and after cycling test.

Keywords: Gel handsanitizer; CMC Na; Stability test; Antibacterial activity

\section{Pendahuluan}

Kulit merupakan lapisan pembungkus tubuh yang selalu mengalami kontak dengan lingkungan luar, baik berupa sinar matahari, iklim maupun faktor-faktor kimiawi dan mekanisme kulit tidak saja harus menghilangkan pengaruh panas matahari, tetapi juga harus dapat mengatasi pengaruh dari sinar matahari, karena itu kulit sangat mudah untuk terinfeksi bakteri (Rostamailis, 2005). Banyak jenis sediaan antibakteri yang bersifat sintetis, dimana penggunaan antibakteri sintetis tersebut lama kelamaan dapat menimbulkan resistensi. Untuk mencegah terjadinya resisten bakteri terhadap sediaan sintetis, maka dibutuhkan sediaan yang terbuat dari bahan alam salah satunya dengan memanfaatkan daun kemangi. Dewasa ini, masyarakat juga semakin cermat dalam memilih pengobatan yang digunakan salah satunya dengan kembali memanfaatkan bahan alam yang mempunyai khasiat yang sama dengan bahan sintetis (back to nature).

Kulit sangat rentan terkena infeksi ataupun penyakit kulit lain yang salah satunya disebabkan oleh bakteri Staphylococcus aureus. Bakteri Staphylococcus aureus bertanggung jawab atas $80 \%$ penyakit supuratif, dengan permukaan kulit sebagai habitat alaminya (Ginanjar, et al., 2010). Penyakit infeksi merupakan salah satu penyakit yang banyak diderita masyarakat Indonesia sejak dulu. Zaman sekarang penyakit infeksi dapat ditanggulangi menggunakan obat modern seperti antibiotik. Penyakit infeksi yang banyak diderita masyarakat adalah infeksi usus yang disebabkan oleh bakteri S. aureus, E. coli, Salmonella typhi, Vibrio cholerae, sedangkan penyebab penyakit infeksi kulit adalah bakteri S. aureus, Pseudomonas aeruginosa dan sebagainya (Oktalia, 2009). Penelitian terdahulu membuktikkan bahwa kandungan flavonoid daun kemangi dapat memberikan efek antibakteri terhadap E. coli, S. aureus, dan K. pneumonia. Penelitian tersebut juga menunjukkan bahwa kombinasi dari kedua senyawa flavonoid daun kemangi yaitu orientin dan visenin memberikan efek antibakteri yang sinergis (saling menguatkan) dibandingkan dengan penggunaan salah satu dari kedua senyawa flavonoid tersebut (Ali \& Dixit, 2012). Adanya indikasi bahwa kombinasi senyawa flavonoid daun kemangi mempunyai daya antibakteri, maka dilakukan uji aktivitas antibakteri ekstrak etanol daun kemangi terhadap pertumbuhan E. coli dan S. aureus. Daun kemangi terbukti memiliki daya hambat yang kuat terhadap bakteri E. coli dan S. aureus (Angelina, et al., 2015). Untuk meningkatkan efektifitas dalam pemanfaatan potensi ekstrak daun kemangi pada penggunaan topikal, maka dibuat dalam bentuk sediaan yang praktis dan mudah digunakan. Salah satu bentuk sediaan yang efektif untuk terapi topikal adalah handsanitizer gel. 
Penggunaan gel handsanitizaer yang praktis dan mudah membuat gel handsanitizer semakin diminati masyarakat. Kebanyakan produk gel handsanitizer saat ini menggunakan bahan aktif alkohol sebagai antibakteri. Penggunaan alkohol dalam sediaan antiseptik dirasa kurang aman terhadap kesehatan karena alkohol merupakan pelarut organik yang dapat melarutkan lapisan lemak dan sebum pada kulit yang berfungsi sebagai pelindung terhadap infeksi mikroorganisme. Selain itu, pemakaian alkohol secara berulang menyebabkan iritasi pada kulit (Dyer, et al., 2000). Sebagai alternatif digunakan bahan alami untuk menggantikan penggunaan alkohol sebagai antibakteri yaitu daun kemangi. Salah satu faktor yang mempengaruhi dalam kualitas sediaan gel antiseptik tangan adalah penggunaan bahan tambahan. Dimana salah satu contoh bahan tambahan yaitu gelling agent yang merupakan eksipien utama dalam pembuatan gel. Salah satu contoh gelling agent yang sering digunakan adalah CMC Na.

Penelitian ini bertujuan untuk mengetahui pengaruh konsentrasi CMC Na sebagai gelling agent terhadap stabilitas fisik dari gel handsanitizer ekstrak daun kemangi sebagai antibakteri. Diharapkan hasil dari penelitian ini dapat menjadi salah satu alternatif antiseptik tangan yang bersumber dari bahan alam.

\section{Bahan dan Metode}

\subsection{Alat}

Neraca analit (Sartorius BP 310P), mikropipet, pH meter (Hanna), pH-indicator strips (E.Merck), pipet volume $1,0 \mathrm{~mL}$ (pyrex), climated chamber suhu $45^{\circ} \mathrm{C}$, lemari pendingin (toshiba), stopwatch (QQ), alat-alat gelas (pyrex), pH meter, penangas air, oven, seperangkat alat uji daya lekat. Bahan utama yang digunakan adalah, $\mathrm{HCl}$, serbuk $\mathrm{Mg}, \mathrm{FeCl}_{3}, \mathrm{CMC} \mathrm{Na}$, propilenglikol, gliserin, nipagin dan essen apel.

\subsection{Bahan}

Daun kemangi segar dari pasar Karanganyar-Indonesia, Jawa Tengah, etanol $96 \%$ p.a (E.Merck), aquadest, $\mathrm{HCl}$ 0,1\% (E.Merck), CMC-Na (Bratachem), $\mathrm{FeCl}_{3}$ (E.Merck), Propilen Glikol (Bratachem), Gliserin (Bratachem), nipagin (Bratachem), esscence appple.

\subsection{Pembuatan serbuk daun kemangi}

Daun kemangi yang masih segar $7 \mathrm{~kg}$ dicuci bersih dan ditiriskan. Daun yang sudah bersih disortasi basah dan ditimbang. Selanjutnya daun dikeringkan menggunakan lemari pengering dengan suhu $45-55^{\circ} \mathrm{C}$. Selanjutnya diblender menjadi serbuk dan dilakukan pengayakan dengan menggunakan ayakan 18.

\subsection{Pembuatan ekstrak daun kemangi}

Maserasi dilakukan dengan memasukkan simplisia daun kemangi yang telah diblender dan diayak. Ditambahkan 5,5 liter etanol 96\% dan dibiarkan selama 5 hari sambil diaduk berulang- 
ulang. Hasil maserat yang diperoleh disaring kemudian dilakukan remaserasi dengan menggunakan etanol 96\%, setelah itu maserat yang telah disaring diuapkan dengan rotary evaporator pada suhu $50^{\circ} \mathrm{C}$ sampai kandungan cairan penyari hilang. Selanjutnya hasil evaporasi diletakkan di waterbath untuk menguapkan sisa cairan penyari dan diperoleh ekstrak kental.

\subsection{Pengujian ekstrak etanol daun kemangi}

\subsubsection{Perhitungan rendeman ekstrak}

Rendemen ekstrak dihitung dengan cara jumlah bobot ekstrak yang diperoleh (gram) terhadap jumlah bobot simplisia awal (gram), yang hasilnya dinyatakan dengan persen (\%) (Depkes, 2000).

\subsubsection{Pemeriksaan organoleptis ekstrak}

Pemeriksaan organoleptis ekstrak dilakukan dengan mengamati secara sederhana dan subyektif menggunakan pancaindera meliputi bentuk, warna, dan bau.

\subsubsection{Identifikasi kandungan flavonoid}

Sampel ekstrak daun kemangi sebanyak 2,0 ml dilarutkan dengan alkohol lalu ditambahkan 2-4 tetes $\mathrm{HCl}$ pekat dan ditambahkan serbuk logam Mg. Reaksi positif jika terjadi perubahan warna kuning menjadi orange/merah (Mariana, et al., 2013).

\subsection{Pembuatan gel handsanitizer ekstrak daun kemangi}

Dibuat 3 formula gel handsanitizer dengan perbedaan konsentrasi variasi CMC Na sebagai gelling agent yang berbeda (Tabel 1). Setelah bahan-bahan ditimbang, CMC Na dikembangkan dalam sebagian aquadest hingga terbentuk basis gel, propilenglikol dan gliserin lalu masukkan dalam basis gel. Nipagin yang sudah dilarutkan sisa aquadest dimasukkan diaduk homogen. Ekstrak yang sudah dilarutkan dengan etanol 96\% dimasukkan diaduk hingga terbentuk massa gel. Kemudian ditetesi dengan essen apel diaduk hingga homogen.

Tabel 1. Formulasi gel handsanitizer ekstrak daun kemangi

\begin{tabular}{cccc}
\hline \multirow{2}{*}{ Bahan } & Formula I & $\begin{array}{c}\text { \% b/b } \\
\text { Formula II }\end{array}$ & Formula III \\
\hline Ekstrak & 3 & 3 & 3 \\
CMC Na & 1 & 2 & 3 \\
Propilenglikol & 15 & 15 & 15 \\
Gliserin & 10 & 10 & 10 \\
Etanol 96\% & 10 & 10 & 0,1 \\
Nipagin & 0,1 & 0,1 & Qs \\
Essen Apel & Qs & Qs & Qs \\
Akuades & Ad 100 & Ad 100 & Ad 100 \\
\hline
\end{tabular}




\subsection{Pengujian gel handsanitizer ekstrak daun kemangi}

\subsubsection{Uji daya lekat}

Sampel 0,25 gram diletakkan diantara 2 obyek gelas, kemudian ditekan dengan beban $1 \mathrm{~kg}$ diatasnya dan dibiarkan 5 menit. Setelah itu obyek gelas diletakkan pada alat dan dilepaskan beban seberat 80 gram, dicatat waktunya sampai obyek gelas terlepas (Miranti, 2009).

\subsubsection{Uji daya sebar}

Sebanyak 0,5 gram sampel gel diletakkan di atas kaca bulat berdiameter $15 \mathrm{~cm}$, kaca lainnya diletakkan di atasnya dan dibiarkan selama 1 menit. Diameter sebar gel diukur.Setelahnya, ditambahkan 150 gram beban tambahan dan didiamkan selama 1 menit lalu diukur diameter yang konstan (Astuti, et al., 2010).

\subsubsection{Uji stabilitas}

\subsubsection{Pengamatan cycling test}

Sediaan disimpan pada suhu $4 \pm 2^{\circ} \mathrm{C}$ selama 24 jam, kemudian dipindahkan ke dalam oven yang bersuhu $40 \pm 2^{\circ} \mathrm{C}$ selama 24 jam (satu siklus). Uji ini dilakukan selama 6 siklus, kemudian diamati adanya pemisahan fase (Banker, 1997).

\subsubsection{Pengukuran diameter globul rata-rata}

Diameter globul rata-rata diukur menggunakan mikroskop optik. Sediaan gel diletakkan pada kaca objek dan diamati dengan mikroskop perbesaran 10 x 10. Gambar yang diamati difoto dan diukur diameter globulnya (Dewi, et al., 2014). Pengukuran diameter globul rata-rata dilakukan pada minggu ke-0 pada suhu ruang, dan setelah dilakukan cycling test.

\subsubsection{Uji aktivitas antibakteri}

Uji aktivitas antibakteri ekstrak daun kemangi terhadap S. aureus dengan metode difusi sumuran, yaitu pada masing-masing media MHA dibuat sumuran yang berdiameter $6 \mathrm{~mm}$ kemudian di isi dengan sediaan gel handsanitizer ekstrak daun kemangi dan menggunakan basis gel sebagai kontrol negatif. Media MHA diinkubasi pada suhu $37^{\circ} \mathrm{C}$ selama $24 \mathrm{jam}$, kemudian diameter zona radikal atau bening yang terbentuk di ukur (Ariani \& Norjannah, 2017).

\section{Hasil dan Pembahasan}

\subsection{Pembuatan serbuk daun kemangi}

Daun kemangi yang segar sebanyak $7 \mathrm{~kg}$ kemudian dicuci dan disortasi basah. Kemudian dikeringkan dengan menggunakan lemari pengering dengan rentan suhu $45-55^{\circ} \mathrm{C}$, daun kemangi dinyatakan kering jika dapat diremas atau dipatahkan dan berubah warna menjadi pucat, didapatkan daun kemangi kering. Setelah daun kemangi kering selanjutnya dilakukan penyerbukan dengan blender. Serbuk daun kemangi yang diperoleh sebanyak 547 gram berwarna hijau kecoklatan. 


\subsection{Pembuatan ekstrak etanol daun kemangi}

Ekstraksi ini menggunakan metode maserasi. Menurut (Ansel, 1989), senyawa-senyawa seperti flavonoid dan tanin merupakan zat aktif yang bersifat polar sehingga diperlukan pelarut polar atau semi polar agar kandungan senyawa dapat tersari. Ekstrak kental daun kemangi yang didapat sebanyak 58,38 gram dengan bentuk kental, warna hijau kehitaman dan berbau khas kemangi. Serta didapatkan bobot rendemen sebesar 10,67\%.

\subsection{Pengujian ekstrak etanol daun kemangi}

\subsubsection{Identifikasi kandungan flavonoid}

Identifikasi kandungan flavonoid dilakukan secara uji kualitatif. Uji senyawa flavanoid menunjukkan hasil positif ditandai dengan terjadinya perubahan warna menjadi jingga, hal ini dikarenakan terjadi reaksi membentuk gelembung-gelembung yang merupakan $\mathrm{H}_{2}$, sedangkan logam $\mathrm{Mg}$ dan $\mathrm{HCl}$ pekat pada uji ini bereaksi untuk mereduksi inti benzopiron yang terdapat pada struktur flavonoid sehingga terbentuk perubahan warna menjadi merah atau jingga. Flavonoid bersifat polar dan bersifat antibakteri dengan mekanisme kerjanya mendenaturasi protein sel bakteri dan merusak membran sel tanpa bisa diperbaiki lagi (Pelezar \& Chan, 1998).

\subsubsection{Pengujian gel handsanitizer ekstrak daun kemangi}

\subsubsection{Uji organoleptis}

Uji organoleptis merupakan pengujian yang dilakukan secara kasat mata atau pengamatan secara langsung untuk mendeskripsikan sediaan tersebut. Uji organoleptis meliputi bentuk atau konsistensi, warna, dan bau dari sediaan yang dihasilkan. Ekstrak daun kemangi ini menunjukkan bentuk kental/pekat, warna hijau kehitaman dan bau khas kemangi. Tujuan dari uji organoleptis yaitu untuk mengetahui apakah terdapat perubahaan secara organoleptis pada sediaan gel handsanitizer ekstrak daun kemangi selama 4 minggu penyimpanan pada suhu kamar

Dari penelitian yang dilakukan, diketahui bahwa ketiga formula tersebut berdasarkan uji sifat fisik memiliki perbedaan, hal ini disebabkan karena jenis gelling agent yang digunakan memiliki konsistensi berbeda. Pada hasil pengujian masing-masing formula menunjukkan tidak terjadinya perubahan bentuk, konsistensi, warna, dan bau yang bermakna pada sediaan gel handsanitizer ekstrak daun kemangi selama penyimpanan suhu kamar selama 4 minggu. Sehingga dapat disimpulkan bahwa ketiga formula tersebut stabil (Tabel 2).

\subsubsection{Uji homogenitas}

Uji homogenitas ini dilakukan dengan tujuan untuk mengetahui homogenitas gel handsanitizer ekstrak daun kemangi dengan melihat keseragaman partikel dalam sediaan tersebut. Ketiga formula sediaan gel handsanitizer ekstrak daun kemangi memiliki susunan yang homogen ditandai dengan tidak ada bagian yang tidak tercampurkan dengan baik selama 4 
minggu penyimpanan (Tabel 3). Dengan demikian, semua sediaan gel mempunyai homogenitas yang baik dan memenuhi persyaratan Farmakope Indonesia edisi III, yaitu jika gel dioleskan pada sekeping kaca atau bahan transparan lain yang cocok harus menunjukkan susunan yang homogen yang dapat dilihat dengan tidak adanya partikel yang bergerombol dan menyebar secara merata.

Tabel 2. Hasil uji organoleptis 3 formulasi gel handsanitizer ekstrak daun kemangi meliputi konsistensi warna dan bau selama 4 minggu.

\begin{tabular}{|c|c|c|c|c|c|c|c|}
\hline \multirow{2}{*}{ Formula } & \multirow{2}{*}{ Organoleptis } & \multicolumn{5}{|c|}{ Minggu ke- } & \multirow{2}{*}{$\begin{array}{c}\text { Setelah } \\
\text { cycling test }\end{array}$} \\
\hline & & 0 & 1 & 2 & 3 & 4 & \\
\hline \multirow{4}{*}{$\mathrm{F} 1$} & Konsistensi & $\begin{array}{l}\text { Sedikit } \\
\text { cair }\end{array}$ & $\begin{array}{c}\text { Sedikit } \\
\text { cair }\end{array}$ & $\begin{array}{c}\text { Sedikit } \\
\text { cair }\end{array}$ & $\begin{array}{c}\text { Sedikit } \\
\text { cair }\end{array}$ & $\begin{array}{c}\text { Sedikit } \\
\text { cair }\end{array}$ & Sedikit cair \\
\hline & Warna & Hijau & Hijau & Hijau & Hijau & Hijau & Hijau \\
\hline & \multirow{2}{*}{ Bau } & Khas & Khas & Khas & Khas & Khas & \multirow{2}{*}{ Khas apel } \\
\hline & & Apel & Apel & Apel & Apel & Apel & \\
\hline \multirow{5}{*}{$\mathrm{F} 2$} & Koncistensi & Cukup & Cukup & Cukup & Cukup & Cukup & \multirow{2}{*}{ Cukup kental } \\
\hline & Konsistens1 & kental & kental & kental & kental & kental & \\
\hline & Warna & Hijau & Hijau & Hijau & Hijau & Hijau & Hijau \\
\hline & \multirow{2}{*}{$\mathrm{Bau}$} & Khas & Khas & Khas & Khas & Khas & \multirow{2}{*}{ Khas apel } \\
\hline & & Apel & Apel & Apel & Apel & Apel & \\
\hline \multirow{4}{*}{ F3 } & Konsistensi & Kental & Kental & Kental & Kental & Kental & Kental \\
\hline & Warna & Hijau & Hijau & Hijau & Hijau & Hijau & Hijau \\
\hline & \multirow{2}{*}{$\mathrm{Bau}$} & Khas & Khas & Khas & Khas & Khas & \multirow{2}{*}{ Khas apel } \\
\hline & & Apel & Apel & Apel & Apel & Apel & \\
\hline
\end{tabular}

Tabel 3. Hasil uji homogenitas 3 formulasi gel handsanitizer ekstrak daun kemangi selama 4 minggu.

\begin{tabular}{ccccccc}
\hline Formula & \multicolumn{5}{c}{ Minggu ke- } & Setelah \\
& 0 & 1 & 2 & 3 & 4 & cycling test \\
\hline F1 & Homogen & Homogen & Homogen & Homogen & Homogen & Homogen \\
F2 & Homogen & Homogen & Homogen & Homogen & Homogen & Homogen \\
F3 & Homogen & Homogen & Homogen & Homogen & Homogen & Homogen \\
\hline
\end{tabular}

Dari uji homogenitas antar formula ini dapat disimpulkan bahwa tidak terdapat perbedaan dari homogenitas sediaan gel hansanitizer ekstrak daun kemangi. Dengan demikian dapat diketahui bahwa perbedaan kosentrasi CMC Na sebagai gelling agent tidak berpengaruh terhadap homogenitasnya.

\subsubsection{Uji $\mathrm{pH}$}

Pemeriksaan pH merupakan salah satu dari uji secara kimia dalam menentukan kestabilan sediaan gel selama penyimpanan. Kestabilan pH selama penyimpanan harus diperhatikan. Nilai 
pH sediaan yang dapat diterima oleh kulit yakni antara 6-8 (Emma, et al., 2014). Pengujian pH dilakukan untuk mengetahui stabilitas $\mathrm{pH}$ tiap formula gel yang dibuat sesuai atau tidak dengan pH kulit, karena apabila tidak sesuai dengan pH kulit maka akan dapat mengakibatkan iritasi apabila terlalu asam, dan dapat mengakibatkan kulit bersisik bila terlalu basa (Anief, 1987). Pengujian ini dimaksudkan untuk mengetahui pengaruh perbedaan konsentrasi basis gel terhadap perubahan $\mathrm{pH}$. Dari hasil pengujian $\mathrm{pH}$ yang dilakukan selama penyimpanan 4 minggu diketahui bahwa nilai $\mathrm{pH}$ yang diperoleh dari ketiga formulasi tersebut masih berada pada rentang $\mathrm{pH}$ sediaan yang dapat diterima oleh kulit, sehingga dapat dipastikan bahwa gel yang dihasilkan memiliki rentang $\mathrm{pH}$ yang tergolong aman karena mendekati $\mathrm{pH}$ netral. Dari ketiga formula, terlihat bahwa adanya perbedaan konsentrasi gelling agent $\mathrm{CMC} \mathrm{Na}$ tidak memberikan pengaruh terhadap pH sediaan (Tabel 4).

Tabel 4. Hasil uji pH 3 formulasi gel handsanitizer ekstrak daun kemangi selama 4 minggu.

\begin{tabular}{ccccccc}
\hline Formula & \multicolumn{5}{c}{ Minggu ke- } & Setelah \\
& 0 & 1 & 2 & 3 & 4 & cycling test \\
\hline F1 & $6,53 \pm 0,05$ & $6,56 \pm 0,03$ & $6,63 \pm 0,04$ & $6,68 \pm 0,05$ & $6,68 \pm 0,02$ & $6,01 \pm 0,02$ \\
F2 & $6,55 \pm 0,07$ & $6,58 \pm 0,05$ & $6,64 \pm 0,05$ & $6,71 \pm 0,02$ & $6,71 \pm 0,03$ & $6,99 \pm 0,02$ \\
F3 & $6,57 \pm 0,03$ & $6,59 \pm 0,03$ & $6,65 \pm 0,07$ & $6,75 \pm 0,06$ & $6,75 \pm 0,04$ & $6,67 \pm 0,02$ \\
\hline
\end{tabular}

\subsubsection{Uji daya sebar}

Pengujian daya sebar dilakukan untuk mengetahui kemampuan gel handsanitizer ekstrak daun kemangi menyebar pada permukaan kulit. Sediaan setengah padat diharapkan mampu menyebar dengan mudah pada tempat pemberian, tanpa ada tekanan yang berarti. Semakin mudah dioleskan pada kulit maka luas permukaan kontak zat berkhasiat dengan kulit akan semakin besar dan absorbsi obatnya akan semakin optimal pula. Hasil pengujian yang dilakukan, menunjukkan bahwa peningkatan luas area sebar disertai dengan adanya penambahan beban yang diberikan, dan hasil yang paling baik terdapat pada formula 3 karena memiliki nilai daya sebar yang masuk dalam skala daya sebar yang baik. Sediaan semisolid yang nyaman digunakan memiliki daya sebar $5 \mathrm{~s} / \mathrm{d} 7 \mathrm{~cm}$ (Garg, A, et al., 2002). Walaupun demikian semua formula dapat dikatakan memiliki stabilitas yang baik untuk penyimpanan selama 4 minggu baik sebelum maupun setelah setelah cycling test (Tabel 5). Daya sebar yang baik menyebabkan kontak antara obat dengan kulit berlangsung cepat. Kenaikan dan penurunan daya sebar sangat dipengaruhi oleh konsistensi gel tersebut, dimana hal ini berhubungan dengan nilai viskositas sediaan. Apabila nilai viskositas sediaan tinggi maka luas daya sebar yang dihasilkan rendah, dan sebaliknya. Hal tersebut terjadi karena viskositas yang tinggi menyebabkan gel sulit mengalir 
sehingga luas area sebar yang dihasilkan kecil (Arista, et al., 2013). Dari ketiga formula dapat dilihat bahwa adanya perbedaan konsentrasi CMC Na sebagai gelling agent memberikan pengaruh terhadap penurunan daya sebar sediaan gel handsanitizer antar formula, dimana semakin tinggi konsentrasi CMC Na maka daya sebarnya akan semakin turun. Hal ini serupa dengan penelitian dari (Supomo, et al., 2015) yang menyebutkan bahwa daya sebar yang kecil disebabkan karena adanya peningkatan konsentrasi gelling agent CMC Na. Salah satu faktor yang mempengaruhi daya sebar gel adalah jumlah dan kekuatan matriks gel. Semakin banyak dan kuat matriks gel maka daya sebar akan berkurang. Dalam sistem gel yang bertanggung jawab terhadap pembentukan matriks gel adalag gelling agent. Dengan demikian konsentrasi gelling agent menambah dan memperkuat matriks gel. Oleh karena itu faktor dominan yang menentukan respon daya sebar adalah $\mathrm{CMC} \mathrm{Na.}$

Tabel 5. Hasil uji daya sebar 3 formulasi gel handsanitizer ekstrak daun kemangi selama 4 minggu.

\begin{tabular}{ccccccc}
\hline $\begin{array}{c}\text { Formula } \\
(\mathrm{cm})\end{array}$ & 0 & 1 & 2 & 3 & 4 & $\begin{array}{c}\text { Setelah } \\
\text { cycling } \\
\text { test }\end{array}$ \\
\hline F1 & $8,54 \pm 0,59$ & $8,56 \pm 0,59$ & $8,59 \pm 0,46$ & $8,62 \pm 0,39$ & $8,62 \pm 0,41$ & $8,65 \pm 0,32$ \\
F2 & $7,37 \pm 0,86$ & $7,40 \pm 0,80$ & $7,42 \pm 0,79$ & $7,45 \pm 0,80$ & $7,45 \pm 0,29$ & $6,99 \pm 0,27$ \\
F3 & $6,80 \pm 1,15$ & $6,83 \pm 1,07$ & $6,85 \pm 0,95$ & $6,88 \pm 0,86$ & $6,88 \pm 0,58$ & $7,10 \pm 0,36$ \\
\hline
\end{tabular}

\subsubsection{Uji daya lekat}

Uji daya lekat ini dilakukan dengan tujuan untuk mengetahui seberapa lama waktu pelekatan gel handsanitizaer daun kemangi pada permukaan kulit sehingga zat aktif dalam sediaan terabsorbsi. Semakin lama gel melekat pada kulit maka efek yang ditimbulkan juga semakin besar menyebar pada permukaan kulit (Ansel, 1989).

Dari tabel IX diatas dapat diketahui bahwa formula gel handsanitizer ekstrak daun kemangi memiliki nilai daya lekat yang berbeda. Semakin besar kosentrasi CMC Na dalam sediaan semakin besar daya lekat sediaan tersebut. Ketiga formula memiliki daya lekat yang baik. Tidak ada persyaratan khusus mengenai daya lekat, namun sebaiknya daya lekat sediaan semi padat adalah lebih dari 1 detik (Zats \& Gregory, 1996). Semua formula dapat dikatakan memiliki stabilitas yang baik untuk penyimpanan selama 4 minggu maupun setelah setelah cycling test. Dari ketiga formula terlihat bahwa adanya perbedaan konsentrasi CMC Na sebagai gelling agent menunjukkan ada perbedaan terhadap data uji daya lekat sediaan gel handsanitizer antar formula (Tabel 6). 
Tabel 6. Hasil uji daya lekat 3 formulasi gel handsanitizer ekstrak daun kemangi selama 4 minggu.

\begin{tabular}{ccccccc}
\hline $\begin{array}{c}\text { Formula } \\
\text { (detik) }\end{array}$ & 0 & 1 & 2 & 3 & 4 & $\begin{array}{c}\text { Setelah } \\
\text { cycling test }\end{array}$ \\
\hline F1 & $1,89 \pm 0,14$ & $1,88 \pm 0,09$ & $1,91 \pm 0,28$ & $2,04 \pm 0,17$ & $2,14 \pm 0,07$ & $1,86 \pm 0,32$ \\
F2 & $3,75 \pm 0,13$ & $3,58 \pm 0,12$ & $3,63 \pm 0,15$ & $3,63 \pm 0,08$ & $3,80 \pm 0,09$ & $3,21 \pm 0,22$ \\
F3 & $5,14 \pm 0,14$ & $4,96 \pm 0,14$ & $5,37 \pm 0,07$ & $4,89 \pm 0,05$ & $5,23 \pm 0,07$ & $4,89 \pm 0,12$ \\
\hline
\end{tabular}

\subsubsection{Uji stabilitas}

Dari hasil uji pengamatan organoleptis, uji homogenitas dan uji pH maupun uji sifat fisik lainnya setelah cycling test, menunjukkan tidak ada perubahan berarti yang terjadi (stabil) dan tidak adanya pemisahan fase pada sediaan gel handasnitizer. Dari hasil pengukuran diameter globul rata-rata, ukuran diameter globul rata-rata cenderung terjadi peningkatan maupun penurunan setelah dilakukan uji cycling test (Tabel 7), namun walaupun demikian, ukuran diameter globul dari gel handsanitizer tetap berada pada kisaran $0,1-10 \mu \mathrm{m}$, sesuai dengan standar literatur (Alfred, et al., 1993).

Tabel 7. Hasil pengamatan diameter globul 3 formulasi gel handsanitizer ekstrak daun kemangi selama 4 minggu.

\begin{tabular}{ccc}
\hline Formula & Sebelum cycling test & Setelah cycling test \\
\hline Formula I & 3,64 & 2,42 \\
Formula II & 3,71 & 3,93 \\
Formula III & 2,82 & 2,64 \\
\hline
\end{tabular}

\subsubsection{Uji aktivitas antibakteri}

Hasil penelitian menunjukkan bahwa sediaan gel handsanitizer ekstrak daun kemangi memiliki aktivitas antibakteri terhadap S. aureus, sedangkan pada konsentrasi 0\% (kontrol negatif) tidak terbentuk zona hambat (Tabel 8). Pada kontrol negatif hanya menggunakan basis gel saja untuk membuktikan bahwa zona hambat yang terbentuk bukan disebabkan oleh eksipen yang digunakan, melainkan disebabkan oleh senyawa-senyawa antimikroba pada daun kemangi. Adanya efek antibakteri pada gel handsanitizer tersebut dikarenakan daun kemangi mengandung beberapa senyawa kimia yakni flavonoid, saponin dan tanin. Berdasarkan hasil uji kandungan flavonoid, daun kemangi positif mengandung adanya flavonoid, yang bersifat antibakteri (Angelina, et al., 2015).

Flavonoid merupakan senyawa aktif yang dapat digunakan sebagai antibakteri, antiflamasi, dan antijamur. Mekanisme flavonoid dalam menghambat pertumbuhan jamur yakni dengan 
menyebabkan gangguan permeabilitas membran sel jamur. Gugus hidroksil yang terdapat pada senyawa flavonoid menyebabkan perubahan komponen organik dan transport nutrisi yang akhirnya akan mengakibatkan timbulnya efek toksik terhadap jamur. Dari ketiga formula terlihat bahwa adanya perbedaan konsentrasi CMC Na sebagai gelling agent menunjukkan ada pengaruh negatif terhadap data uji aktifitas antibakteri sediaan gel handsanitizer antar formula, dimana semakin tinggi konsentrasi CMC Na maka aktifitas antibakteri akan semakin turun. Hal tersebut dilihat dari hasil rerata diameter zona hambat yang menunjukkan bahwa terjadi penurunan diameter zona hambat pada setiap formula. Penurunan rerata diameter zona hambat disebabkan karena adanya peningkatan konsentrasi Na CMC. Dengan meningkatnya konsentrasi NA CMC, maka kecepatan difusi senyawa antibakteri juga akan semakin lama, hal ini dikarenakan semakin meningkatnya konsentrasi Na CMC maka akan meningkatkan viskositas suatu sediaan, dan semakin besar viskositas suatu sediaan maka semakin besar pula tahanannya (Sinko, 2011) sehingga menghalangi pelepasan dari zat aktif tersebut dan mengakibatkan penurunan hambatan pada formulasi gel terhadap bakteri S. aureus.

Tabel 8. Hasil diamter zona hambat sediaan 3 formulasi gel handsanitizer ekstrak daun kemangi terhadap baketeri Staphylococcus aureus

\begin{tabular}{cc}
\hline Formula & Diameter zona hambat $(\mathbf{m m})$ \\
\hline Kontrol negatif & - \\
Formula I & $25,26 \pm 0,32$ \\
Formula II & $25,45 \pm 0,42$ \\
Formula III & $21,78 \pm 0,37$ \\
\hline
\end{tabular}

\section{Kesimpulan}

Semakin tinggi penggunaan konsentrasi CMC Na sebagai gelling agent maka konsistensi gel mejadi semakin meningkat, daya lekat semakin lama, daya sebar semakin kecil, dan aktifitas antibakterinya semakin menurun. Namun perbedaan konsentrasi CMC Na mempengaruhi terhadap hasil uji pH dan homogenitas. Gel handsanitizer ekstrak daun kemangi memiliki stabilitas yang baik sebelum maupun sesudah cycling test.

\section{Ucapan Terimakasih}

Ucapan terimakasih kepada Universitas Sebelas Maret Surakarta, atas hibah dana PNBP program Penelitian Fundamental tahun 2018 yang telah diberikan sehingga penelitian ini terlaksana dengan baik dan lancar. 


\section{Daftar Pustaka}

Alfred, M., James, S., dan Arthur, C. (1993). Dasar Dasar Kimia Fisik dalam Ilmu Farmasetik, In Yoshita (Ed.). Jakarta: UI Press.

Ali, H. dan Dixit, S. (2012). In Vitro antimicrobial activity of flavanoids of Ocinum sanctum with synergistic effect their comboned form. Asian Pasific Journal of Tropical Disease, 396-398.

Angelina, M., Turnip, M., dan Khotimah, S. (2015). Uji Aktivitas Ekstrak Etanol Daun Kemangi (Ocinum sanctum L.) Terhadap Pertumbuhan Bakteri Escherichia coli dan Staphylococcus aureus. Protobiont, 4(1), 184-189.

Anief, M. (1987). Ilmu Farmasi. Yogyakarta: Gadjah Mada University Press.

Ansel. (1989). Pengantar Bentuk Sediaan Farmasi, (Keempat ed.). Jakarta: UI Press.

Ariani, N. dan Norjannah. (2017). Daya Hambat Ekstrak Etanol Kulit Buah Pisang Kepok Mentah (Musa paradisiaca forma typica) Terhadap Pertumbuhan Escherichia coli Secara In Vitro. Jurnal Ilmiah Ibnu Sina, 2(2), 296-303.

Arista, Y.N., Paulina, V.Y. dan Hamidah, S. (2013). Formulasi dan Uji Aktivitas Gel Antijerawat Ekstrak Umbi Baku (Crinum asiaticum L.) Terhadap Bakteri Staphylococcus aureus Secara In Vitro. Jurnal Ilmiah Kefarmasian, 2(2), 18-26.

Astuti, I.Y., Hartati, D. dan Aminiati, A. (2010). Peningkatan Aktivitas Antijamur Candida albicans Salep Minyak aaatsiri Daun Sirih (Piper bettle LINN.) melalui Pembentukan Kompleks Inklusi dengan $\beta$-sikloodekstrin. Majalah Obat Tradisional, 15, 94-99.

Banker, G. (1997). Modern Pharmaceutics Drugs and the Pharmaceutical Science' (7 ed.). New York: Marcel Dekker Inc.

Depkes. (2000). Parameter Standar Umum Ekstrak Tumbuhan Obat'. Jakarta: Dirjen POM, Departemen Kesehatan RI.

Dewi, R., Anwar, E. dan Yunita, K.S. (2014). Uji Stabilitas Fisik Formula Krim yang Mengandung Ekstrak Kacang Kedelai (Glycine max). Pharm Sci Res, 1(3).

Ditjen POM. (1985). Formularium Kosmetika Indonesia. Jakarta: Departemen Kesehatan Republik Indonesia.

Dyer, D., Shinder, A. dan Shinder, F. (2000). Alcohol-free Instant Hand Sanitizer Reduces Elementary School Illnes Absenteeism. Family Medicine, 32(9), 633-638.

Emma, S., Iskandarsyah, dan Praptiwi. (2014). EVALUASI, UJI STABILITAS FISIK DAN SINERESIS SEDIAAN GEL YANG MENGANDUNG MINOKSIDIL, APIGENIN DAN PERASAN HERBA SELEDRI (Apium graveolens L.). Buletin Penelitian Kesehatan, 42(2), 213-222.

Garg, A., Aggarwal, D., Garg, S. dan Sigla, A,K. (2002). Spreading of Semisolid Formulation : An Update. Journal Pharmaceutical Technology, 20(2), 84-102.

Ginanjar, E., Retnaningrum, E., Septriani, N., Octaviani, A., Wiyati, D. dan Rosrinda, E. (2010). Handy Gel Carrota Hasil Fermentasi Daun Wortel Sebagai Antibakteri Penyebab Penyakit Kulit. Seminar Nasional Biologi, Fakultas Biologi Universitas Gadjah Mada, Yogyakarta, p. 1169.

Mariana, L., Andayani, D. dan Ryantin, G. (2013). Analisis Senyawa Flavonoid Hasil Fraksinasi Ekstrak Diklorometana Daun Keluwih (Artocarpus camansi). Chem.Prog, 6 (2), 50-55. 
Miranti, L. (2009). Pengaruh Konsentrasi Minyak Atsiri Kencur (Kaemferia galangal) Dengan Basis Salep Larut Air Terhadap Sifat Fisik Salep dan Daya Hambat Bakteri Staphylococcus aureus Secara In Vitro. Skripsi, Fakultas Farmasi Universitas Muhammadiyah Surakarta.

Oktalia, D. (2009). Isolasi Streptomyces dari Familia Poaceae yang Berpotensi Menghasilkan Antibiotik Terhadap Staphylococcus aureus. Skripsi, Fakultas Farmasi Universitas Muhammadiyah Surakarta.

Pelezar, M. dan Chan, E. (1998). Dasar-Dasar Mikrobiologi 2, Penerjemah : R,S, Hadioetomo;T, Imas; S,S,Tjitrosomo. Jakarta: UI Press.

Rostamailis. (2005). Perawatan Badan, Kulit, dan Rambut. Jakarta: PT. Rineka Cipta.

Sinko, P. J. (2011). Martin Farmasi Fisila Dan Ilmu Farmasetika, diterjemahkan oleh Tim Alih Bahasa Sekolah Farmasi ITB (5 ed.). Jakarta: Buku Kedokteran EGC.

Supomo, Sukawaty, Y. dan Baysar, F. (2015). Formulasi Gel Handsanitizer dari Kitosan dengan Basis Natrium Karboksimetilselulosa. Jurnal Ilmiah Manuntung, 1(1), 31-37.

Tranggono, Iswari, R., Latifah dan Fatmah. (2007). Buku Pegangan Ilmu Pengetahuan Kosmetik. Jakarta: PT. Gramedia Pustaka Utama.

Zats, J. dan Gregory, P. (1996). Gel, in Lieberman, H,A;Rieger, M,M;Banker,G.S., Pharmaceutical Dosage Form : Disperse Systems' (2 ed.). New York: Marcel Dekker Inc. 